\title{
On the thiamine content of some edible mushrooms
}

\author{
SEIJA MÄKINEN, RAKEL KURKELA and TUULA PARIKKA
}

\begin{abstract}
MAKKINEN, S. M., KURKELA, R. \& PARIKKA, T, 1978: On the thiamine content of some edible mushrooms. - Karstenia is (suppl.).

The thiamine content of fresh wild mushrooms varied between $1160 \mu \mathrm{g} / 100 \mathrm{~g}$ dry matter (Lactarius necator) and $430 \mu \mathrm{g} / 100 \mathrm{~g} \mathrm{d.m.} \mathrm{(Tricholoma} \mathrm{portentosum)} \mathrm{the} \mathrm{caps} \mathrm{containing}$ more than the stipes. The thiamine content increased during storage of fresh mushrooms in the refrigerator in polyethylene bags. For example, storage for one week at $4^{\circ} \mathrm{C}$ doubled the refrigerator in polyethylene bags. For example, storage for one week at $4^{\circ} \mathrm{C}$ doubled
the thiamine content of fresh Agaricus bisporus, while two weeks storage increased it the thiamine content of fresh Agaricus bisporus, while two weeks storage increased it
threefold; both increases being statistically highly significant $(P<0.001)$. The thiamine content of pleurotus ostreatus stored at $4^{\circ} \mathrm{C}$ also increased significantly; that of Cantharellus cibarius stored at $4^{\circ} \mathrm{C}$ and at $10^{\circ} \mathrm{C}$ for three months, however, increased more at $10^{\circ} \mathrm{C}$ than at $4^{\circ} \mathrm{C}$.

The thiamine content of frozen mushrooms was highest in Gyromitra esculenta (1350 $\mu \mathrm{g} / 100 \mathrm{~g} \mathrm{d.m.)}$ and nearly as much was found in Leccinum vulpinum. The thiamine content decreased after two months storage in the freezer, the decrease being highly significant decreased after $(P<0.001)$.

The content of thiamine in freeze-dried and drum-dried mushrooms was on the average lower than in the fresh ones.

S. M. Mäkinen \& T. Parikka, Department of Nutrition, University of Helsinki, SF-00710 Helsinki, Finland.

R. Kurkela, Departoment of Food Chemistry and Technology, University of Helsinki, SF-00710 Helsinki 71, Finland.
\end{abstract}

\section{Introduction}

In the literature the vitamin content of mushrooms varies much according to study, species, habitat, etc, the results concerning even the same vitamin being rather contradictory (Block et al. 1953, Bötticher 1968, Litchfield 1964, Mlodecki et al. 1973 a, b, c). According to Karosiene (1973, 1974) the thiamine content of fresh Boletus varies from $1.55 \mathrm{mg}$ to $11.7 \mathrm{mg}$ per $100 \mathrm{~g}$ and that of dried B. scaber is $0.89 \mathrm{mg} / 100 \mathrm{~g}$. Generally speaking, mushrooms are not held to be any excellent sources of vitamins, although they may be significant in some special conditions, for example in vegetarian diets.

Since there did not exist any investigations concerning the vitamin content of Finnish edible fungi, analyses were started by determining the thiamine content of some wild and cultivated Finnish mushrooms in the summer of 1976.

\section{Materials and methods}

\section{Mushrooms}

Fresh: Flammulina velutipes and Pleurotus ostreatus were cultivated by Dr. Roponen at the Biochemical Research Institute, Helsinki. Fresh Agaricus bisporus were obtained from two Finnish commercial cultivators. Albatrelzus ovinus, Cantharellus cibarius, Cortinarius armiliatus, Lactarius necator, Naematoloma capnoides and Tricholoma portentosum were picked from forests in 1976.
All fresh mushrooms were stored in polyethylene bags at $4^{\circ} \mathrm{C}$.

Frozen: Boletus edulis, c. cibarius, Gyromitra esculenta, Lactarius rufus, L. torminosus, L. trivialis and Leccinum vulpinum were obtained from Valio Finnish Co-operative Dairies' Association. They were from the crop of 1976 and were stored in polyethylene bags at $-20^{\circ} \mathrm{C}$.

Dried: Freeze-dried A. ovinus, Cortinarius armillatus, $C$. triumphans, Hydnum rufescens, Lactarius necator, L. torminosus, and $N$. capnoides were obtained from the Department of Botany, University of Helsinki, and $F$. velutipes from the Department of Botany, University of Turku. Powdered drum-dried $L$. rufus and $L$. trivialis were prepared at the Department of Food Chemistry and Technology, University of Helsinki.

All dried mushrooms were stored in polyethylene bags at room temperature.

The thiamine content of mushrooms was determined by the fluorometric method of AOAC (1970). The yield was $94 \pm 1.9 \%$ when a known amount of thiamine was added to a homogenized mushroom preparation.

\section{Results and discussion}

The thiamine content of fresh wild mushrooms varied between $1160 \mu \mathrm{g} / 100 \mathrm{~g} \mathrm{~d} . \mathrm{m}$. in $\mathrm{L}$. necator and $430 \mu \mathrm{g} / 100$ $\mathrm{g}$ d.m. in $T$. portentosum (Table 1 ). The caps contained more thiamine than the stipes (Table 2), as has been reported also by Karosiene (1973, 1974) for Boletus. 
Table 1. Thiamine content of fresh mushrooms stored at $4^{\circ} \mathrm{C}$ (mean \pm SEM or ranges)

\begin{tabular}{lcc}
\hline Mushroom & $\begin{array}{c}\text { Thiamine } \\
\mu \mathrm{g} / 100 \mathrm{~g} \text { d.m. }\end{array}$ & $\begin{array}{c}\text { Time of storage } \\
\text { days }\end{array}$ \\
\hline Lactarius necator & $1160 \pm 80$ & 16 \\
Albatrellus ovinus & $950 \pm 60$ & 7 \\
Cortinarius armillatus & 870 & 2 \\
Flammulina velutipes & $820-850$ & $2-3$ \\
Naematoloma capnoides & $480 \pm 40$ & 15 \\
Cantharellus cibarius & $440-480$ & $7-96$ \\
Tricholoma portentosum & 430 & 10 \\
Pleurotus ostreatus & $490-840$ & $1-9$ \\
Agaricus bisporus & $390-1030$ & $1-16$ \\
\hline
\end{tabular}

Table 2. Thiamine content in the caps and stipes of fresh and frozen mushrooms (mean \pm SEM)

\begin{tabular}{|c|c|c|c|}
\hline \multirow[t]{2}{*}{ Mushroom } & \multicolumn{2}{|c|}{$\begin{array}{l}\text { Thiamine } \\
\mu \mathrm{g} / 100 \mathrm{~g} \text { d.m. }\end{array}$} & \multirow[t]{2}{*}{ Time of storage } \\
\hline & Caps & Stipes & \\
\hline Fresh & & & days at $4^{\circ} \mathrm{C}$ \\
\hline$\overline{\text { Agaricus bisporus }}$ & $730 \pm 40$ & 330 & 8 \\
\hline Naematoloma capnoides & $480 \pm 40$ & 80 & 15 \\
\hline Tricholoma portentosion & 430 & 80 & 10 \\
\hline Agarious bisporus & $400 \pm 30$ & 200 & 1 \\
\hline Frozen & & & months at $-20^{\circ} \mathrm{C}$ \\
\hline Gyromitra esculenta & $1350 \pm 80$ & 450 & 4.5 \\
\hline Leccinum vulpinum & $1260 \pm 70$ & 790 & 2.5 \\
\hline Boletus edulis & $1020 \pm 50$ & 850 & 3 \\
\hline Lactarius trivialis & $860 \pm 20$ & 550 & 2.5 \\
\hline L. mufus & $800 \pm 30$ & 270 & 3 \\
\hline A. bisporus & $500 \pm 30$ & 330 & 3 \\
\hline
\end{tabular}

An astonishing result was that the thiamine content of fresh mushrooms increased during storage in refrigerator in polyethylene bags. For example, storing for one week at $4^{\circ} \mathrm{C}$ doubled the content of fresh Agaricus, while two weeks storage increased it threefold (Fig. 1), both increases being statistically highly significant $(P<0.001)$. The thiamine content of $P$. ostreatus stored at $4^{\circ} \mathrm{C}$ also increased significantly (Fig. 1). C. cibarius was stored at $4^{\circ} \mathrm{C}$ and at $10^{\circ} \mathrm{C}$ for 3 months. The thiamine content increased in both stores, more at $10^{\circ} \mathrm{C}$ than at $4^{\circ} \mathrm{C}$ (Fig. 2).

The thiamine content of frozen mushrooms was highest in G. esculenta, $1350 \mu \mathrm{g} / 100 \mathrm{~g} \mathrm{d.m.,} \mathrm{and} \mathrm{nearly}$ as much was found in $L$. vulpinum (Table 3 ). The content usually decreased when storing at freezer, which is seen in Fig. 3. The decrease in thiamine in false morels stored in freezer for 2 months was highly significant $(P<0.001)$. A highly significant decrease could be seen also in $L$. torminosus and a significant decrease $(P<0.01)$ in $L$. trivialis, while a highly significant increase was detected in $B$. edulis and a significant increase $(\mathrm{P}<0.01)$ in $A$. bisporus. The thiamine content of $C$. cibarius stored in freezer for 4.5 months remained nearly constant (Fig. 3).
Fig. 1. Content of thiamine in two lots of fresh Agaricus bisporus and Pleurotus ostreatus during storage at $4^{\circ} \mathrm{C}$. Mean \pm SEM are indicated.

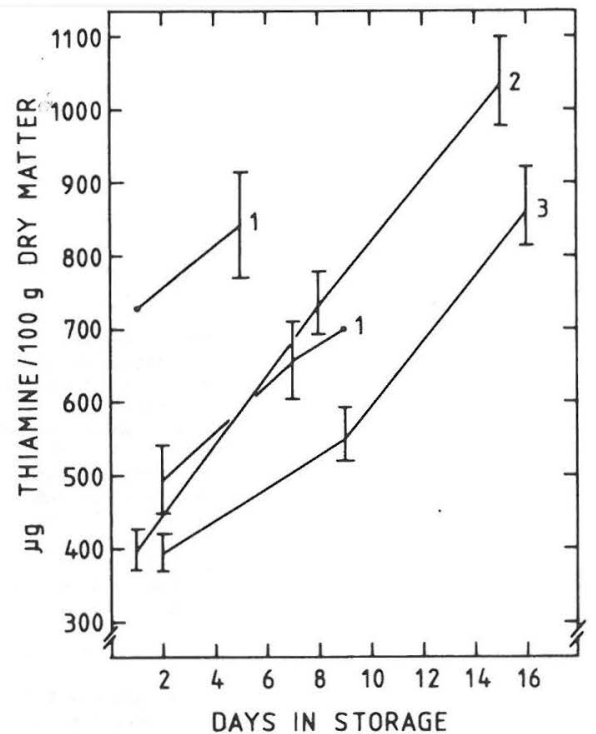

1 PLEUROTUS

2 AGARICUS (PEIKKOLA)

3 AGARICUS (SAUVON SAILYKE)

Fig. 2. Content of thiamine in fresh Cantharelzus cibarius during storage at $4^{\circ} \mathrm{C}$ and at $10^{\circ} \mathrm{C}$. Mean \pm SEM are indicated.

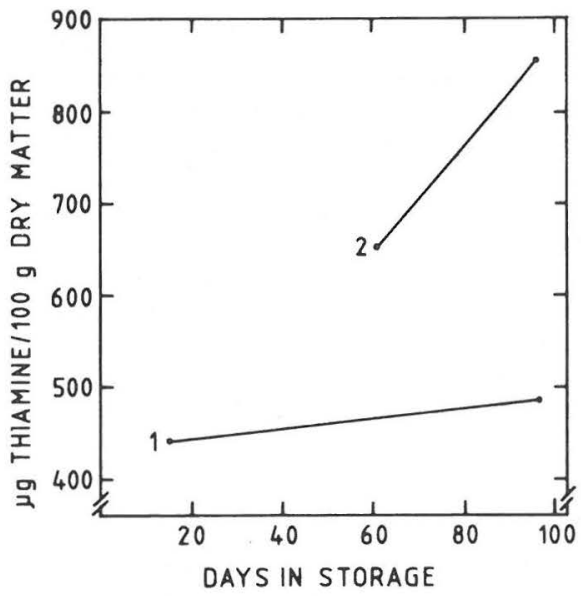

1 CANTHARELLUS CIBARIUS $+4^{\circ} \mathrm{C}$ 2 CANTHARELLUS CIBARIUS $+10^{\circ} \mathrm{C}$ 
Table 3. Thiamine content of frozen mushrooms (mean \pm SEM)

\begin{tabular}{lcc}
\hline Mushroom & $\begin{array}{c}\text { Thiamine } \\
\mu \mathrm{g} / 100 \mathrm{~g} \text { d.m. }\end{array}$ & $\begin{array}{c}\text { Time of storage } \\
\text { months at }-20^{8} \mathrm{C}\end{array}$ \\
\hline Gyromitra esculenta & $1350 \pm 80$ & 6 \\
Leccinum vulpinom & $1340 \pm 75$ & 2.5 \\
Lactarius torminosus & $1110 \pm 60$ & 2 \\
Boletus edulis & $1020 \pm 50$ & 3 \\
Lactarius trivialis & $860 \pm 20$ & 2.5 \\
L. mufus & $800 \pm 30$ & 2.5 \\
Agaricus bisporus & $525 \pm 30$ & 3 \\
Cantharellus cibarius & $375 \pm 30$ & 2.5 \\
\hline
\end{tabular}

Fig. 3. Content of thiamine in frozen mushrooms during storage at $-20^{\circ} \mathrm{C}$. Mean \pm SEM are indicated.

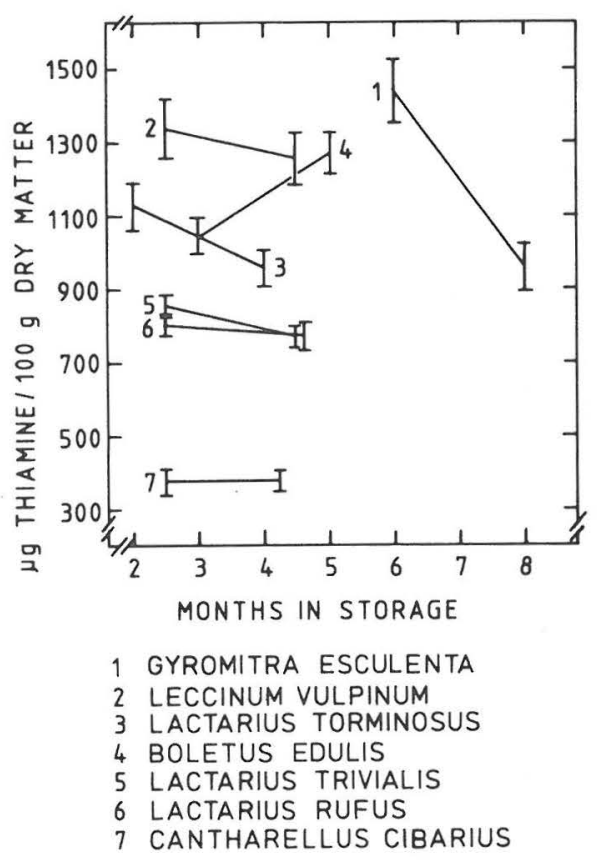

The content of thiamine in freeze-dried and drum-dried mushrooms was on the average lower than in the fresh ones, from 30 to 70 per cent of the amount found in fresh mushrooms (Table 4). Straight conclusions of the effects of freezing on the thiamine content of fresh mushrooms cannot be made on the basis of these experiments, because frozen mushrooms were not from the same place as the fresh ones. The gradual decrease in thiamine when mushrooms are stored in freezer may be due to cell breathing, which occurs although slowly, even at freezer temperature.

It is indeed a fact that the thiamine content may increase during storage at refrigerator temperature, which rarely occurs to any vitamin in foodstuffs
Table 4. Thiamine content of freeze-dried and drum -dried mushrooms

\begin{tabular}{lc}
\hline \multicolumn{1}{c}{ Mushroom } & $\begin{array}{c}\text { Thiamine } \\
\mu \mathrm{g} / 100 \mathrm{~g} \mathrm{~d} \cdot \mathrm{m} .\end{array}$ \\
\hline Freeze-dried: & \\
Lactarius necator & 1310 \\
Albatrellus ovinus & 1030 \\
Lactarius torminosus & 980 \\
Cortinarius armillatus & 610 \\
Flammulina velutipes & 550 \\
Cortinarius triumphans & 370 \\
Naematoloma capnoides & 150 \\
Hydnum rufescens & 120 \\
Drum-dried: & \\
Lactarius rufus & 670 \\
L. trivialis & 640 \\
\hline
\end{tabular}

generally. Karosiene $(1973,1974)$ has reported that old Boletus contain less thiamine than the young ones due to dropping of spores, which are rich in thiamine. Some kind of ripening may explain the increase of thiamine in fresh mushrooms stored in refrigerator and of Agaricus and Boletus in freezer. However, the dependence of changes in thiamine content on the oxygen and carbon dioxide pressure in the package should be studied.

On the basis of these results, mushrooms are a fairly good source of thiamine, the content corresponding to that found in pork, peanuts and rye bread. Before evaluating the real nutritional value of edible fungi, however, the losses occurring in food preparation should also be investigated.

\section{Acknowledgement}

This study has been financed by a grant from the Academy of Finland, for which the authors owe their gratitude. References

AOAC. 1970: Official Methods of Analysis of the Association of Official Analytical Chemists. Washington D.C. pp. 771-774.

Block, S. S., Stearns, T. W., Stephens, R. L. \& McCanless, R. F. J. 1953: Mushroom mycelium experiments with submerged culture. - J. Agr. Food Chem. 30: 890-893.

Bötticher, W. 1968: Pilze und Pilzdauerwaren. In:Handbuch der Lebensmittelchemie V/2. - Springer Verlag, Berlin-Heidelberg. 508-537.

Karosiene, S. 1973: Vitamin content in mushrooms. 4. Thiamine and riboflavin in fruit-bodies of Suillus luteus Gray = Boletus luteus Fr. Lietuvos TSR Mokslu akademijos darbai. C serija 4 (64): 201-211.

-" 1974: Vitamin content in mushrooms.5. Thiamine and riboflavin in fruit-bodies of teccinum scabrum Gray = Boletus scaber Fr. - Lietuvos TSR Mokslu akademijos darbai. C serija l(65): 191-198. 
Litchfield, J. H. 1964: Nutrient content of morel mushroom mycelium. - J. Food Sci. 29: 690-69l.

Mlodecki, H., Wieckowska, E., Janowska, T. \& Kawalska, I. 1973a: Proby okreslania wiraminy $\mathrm{B}_{2} \mathrm{w}$ grzybach za pomoca metody mikrobiologicznej. Bromatologia i Chemia Toksykologiczna 6: 23-28.
Mlodecki, H., Wieckowska, E. \& Jasinska-Sobocinska, A. 1973b: Wplyw blanszowania grzybow na zawartose ryboflawiny. - Bromat. Chem. Toksykol. 6: 261-263.

Mlodecki, H., Wieckowska, E. \& Kuleta-Tomasik, J. 1973c: Wplyw warinkбw suszenia grzybów na zawartosc ryboflawiny. - Bromat. Chem. Toksykol. 6: 29-32. 